\title{
Fiscal Rules and Electoral Turnout
}

\begin{abstract}
A growing literature has argued that electoral turnout decreases the more government policy is constrained by economic and institutional factors. This article investigates whether a certain type of policy constraint, fiscal rules, lowers turnout. Since fiscal rules set limits for government fiscal policy, they should lower the incentive for citizens to participate electorally. However, using parliamentary turnout data in a large panel of democratic countries, little robust evidence is found in favor of fiscal rules having a depressing effect on electoral turnout. Analysis of European individual-level data also suggest that national fiscal rules do not affect inequality in electoral turnout between income groups either. Difference-in-discontinuity evidence from Italian municipalities further suggest that the results are causally identified.
\end{abstract}




\section{Introduction}

The determinants of electoral turnout and other aspects of political participation are classic questions in political science and continues to be at the forefront of the political science research agenda (Wolfinger and Rosenstone 1980; Blais 2006; Cox 2015) as well as normative discussions about democratic politics (Lijphart (1997). A recent revitalized both scholarly and normative discussion is whether constraints on government action reduce citizens' incentive and willingness to participate electorally and thus reduce electoral turnout (Steiner and Martin 2012; Marshall and Fisher 2015; Steiner 2016; Häusermann et al. 2018). This article deals with the subject of policy constraint and electoral turnout in the context of national fiscal rules.

National fiscal rules are of growing importance as governance institutions in these years. National fiscal rules can be defined as rules or rulesets which by national law and/or regulation set numerical limits and/or guidelines for government debt, deficits and even revenue and expenditure (Schaechter et al. 2012, 5). Examples of national fiscal rules could be that the constitution states that the public budget should be in balance, that there exist expenditure ceilings for government expenditure, which the government needs to take into account when drafting the public budget, or the existence of a law which sets a maximum allowed level of public debt as a percentage of GDP. While an active research agenda in public economics assesses the potential effect of fiscal rules on government fiscal policy (Heinemann et al. 2018), the political effects of these types of formal constraints on government fiscal policy remain under-researched in political science. Which is in contrast with the extensive research on the politics of central bank independence (FernandezAlbertos 2015), another potential constraint on government policy. Given that these types of rules deal specifically with constraint on arguable one of the most important aspects of government 
policy - fiscal policy - and seems to be spreading fast among countries, confer figure 1, this lack of scholarly interest is remarkable.

Figure 1: Share of the World's countries with national fiscal rules in place 1985-2014

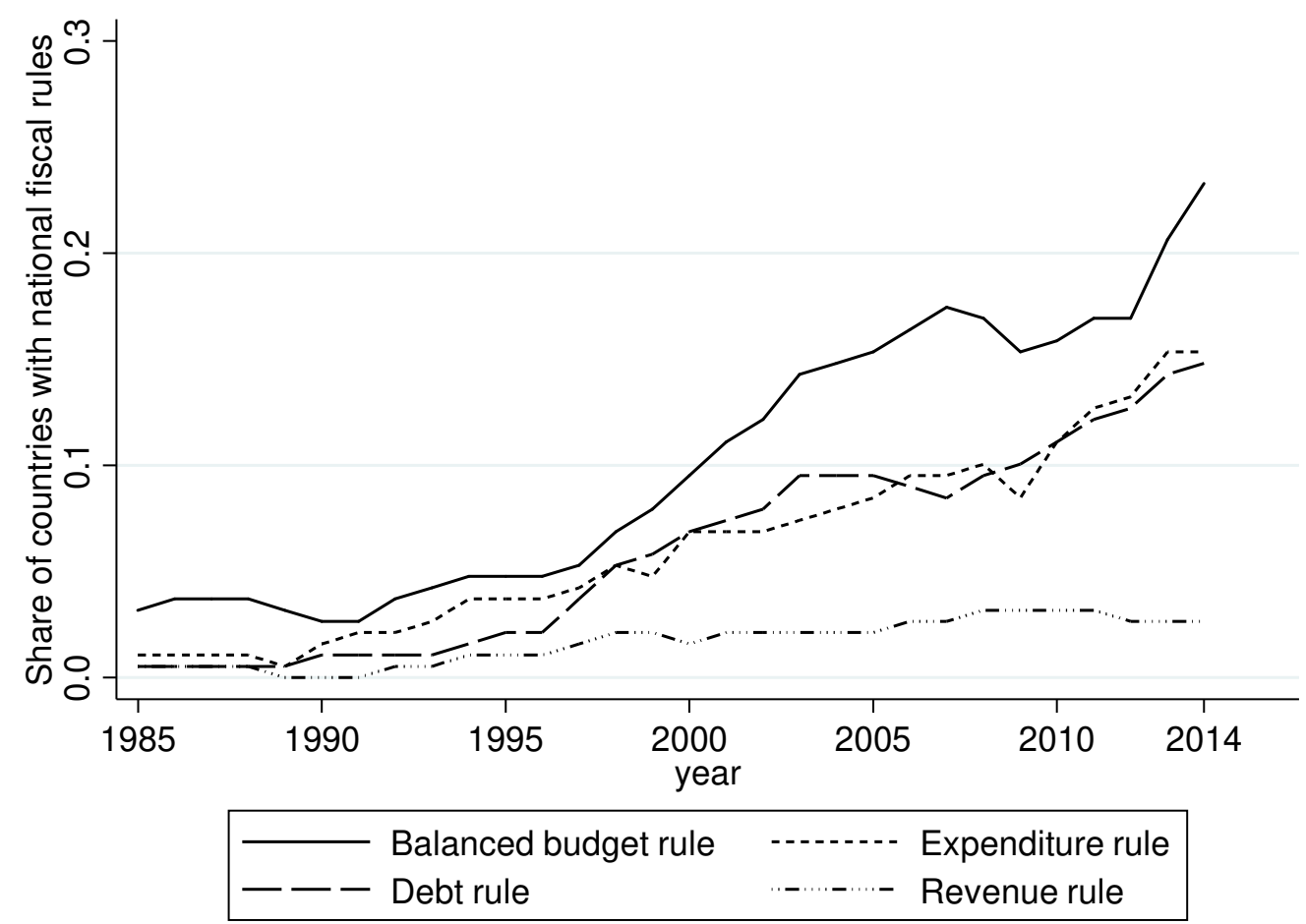

Note: Source is IMF's Fiscal Rules' Database.

As these rules are increasingly being implemented nationally and are being increasingly promoted by international organizations such as the International Monetary Fund (IMF) and the European Union, they are also the subject of normative and public discussions, including their effects on the functioning of national democracy. As noted by the United Nations' and the International Labour Organization's staff members Anis Chowdhury and Iyanatul Islam in a critique of the increased tendency to implement fiscal rules, "If the intention is to remove discretion from politicians, then how can they implement their election manifestos? The national budget is an important instrument for fulfilling promises made by political parties. By removing this instrument, fiscal rules can potentially undermine accountable governance, especially in new democracies. Therefore, one may 
ask, "credibility for whom" - electorates or financial markets? Thus, by trying to enhance the credibility of governments in the eyes of financial markets, fiscal rules can undermine the credibility of a democratic polity." (Chowdhury and Islam 2012).

However, these normative arguments about the potential impact of fiscal rules on national democracy are usually just based on assumptions rather than actual evaluations of the potential effects of these rules. While recent empirical and theoretical work indeed suggest that citizens' engagement with national politics can be negatively affected by formal constraints on government fiscal action (Hortala-Vallve and Larcinese 2017; Häusermann et al. 2018), the democratic effects of the spread of fiscal rules have received no systematic empirical scrutiny. Unlike the issue of globalization and turnout (Steiner and Martin 2012; Marshall and Fisher 2015; Steiner 2016), no empirical research has been done on whether the introduction of fiscal rules will lower electoral turnout and whether these rules affect turnout inequality. This article specifically addresses these issues.

Using parliamentary turnout data in a panel of 103 democracies, this article tests the effect of both the existence and strength of national fiscal rules on electoral turnout. The use of fixed-effects estimation makes it possible to compare turnout levels within countries which experience changes in the fiscal rules framework and thus to better assess whether the enactment of fiscal rules actually reduces electoral turnout. The empirical results, however, lends little support for the argument that fiscal rules depress turnout levels. Only expenditure rules seem to have a clear negative association with electoral turnout and even here the results are not particularly robust, especially when 
restricting the sample to the stable democracies of the OECD, where we should expect fiscal rules to be most effective.

Regarding inequality in turnout, further analysis of individual-level European data also suggest that fiscal rules do not increase inequality in electoral turnout between income groups either. Analysis of fiscal rules in Italian municipalities using a difference-in-discontinuity design provides further causal evidence that fiscal rules do not seem to matter for electoral turnout. While fiscal rules might under some circumstances constrain fiscal policy, they do not seem to affect electoral turnout.

\section{Theory: Fiscal rules as constraints}

The basis for a relationship between fiscal rules and electoral turnout is that the incentive and willingness of citizens to turn out in elections are negatively affected by constraints on future government action, and that fiscal rules can been seen as such a constraint. The general argument for a link between constraints on government action and electoral turnout rests on the classical assumption that one important aspect of citizens' choice of whether to turn out in elections is whether their vote actually matter for future government policy and societal outcomes (Downs $1957,44)$. Constraints on the government's action should mean that the outcome of an election has a more limited chance of actually changing future policy and outcomes, even if the government has changed as a consequences of the election, which in turn reduce voters' propensity to vote in an election. 
This argument follows the logic of a number of voting models. In a study of government constraint and electoral turnout, Marshall and Fisher (2015) model the constraining argument by using the classic calculus-of-voting equation (Riker and Ordeshook 1968), ${ }^{1}$ where increased government policy constraints lower the relative benefit from one's favorite candidate winning in an election which in turn reduces the incentive to vote. Similar results follows from applying other theoretical models of the voting action. Taking the view of the alternative calculus-of-voting model proposed by Franklin (2004), increased formal policy constraints would lower the prospect for an election to bring about any substantive policy changes both positive and negative, which should decrease the substantive competition between the political parties running in the election which again would decrease citizens' incentive to vote (Franklin 2004, 57).

The voting models and arguments mentioned above rest on a very instrumental view of the voting action, which have received substantial criticism in their failure to withhold empirical scrutiny. ${ }^{2}$ However, also more non-instrumental arguments can be made in favor of policy constraints as having a negative effect on turnout. If citizens increasingly view the government as being unable to actually change policy and/or having less legitimacy due to being subject to different rules and external constraints, rather than the wishes of the voters, they could view the voting action as illegitimate and thus be more likely to abstain, see Birch (2010, 1602-1603) and Miles (2015) for

\footnotetext{
${ }^{1} R=P B-C+D$, where $\mathrm{R}$ is the utility from participating in the voting action and thus the incentive to vote. $\mathrm{P}$ is the probability that the voter's own vote is pivotal in bringing the voter's favorite candidate to win, B is the relative benefit the voter gains from having the favorite candidate win, $C$ is the cost of voting, while $D$ is the intrinsic value of voting.

${ }^{2}$ See (Enos and Fowler 2014), (Gerber et al. 2017) and (Moskowitz and Schneer 2018). See also review by Geys (2006).
} 
discussions about legitimacy and turnout. ${ }^{3}$ So for both instrumental and non-instrumental reasons, increased policy constraints in the political sphere should have a negative effect on turnout.

Most scholarship and normative discussions about the effect of policy constraint on electoral turnout has dealt with globalization and other types of international economic integration (Steiner and Martin 2012; Marshall and Fisher 2015; Steiner 2016). The central argument in these studies is that increasing economic interdependence and capital mobility will constrain national governments in the economic policies they are able to pursue and thus reduce voters' incentive to participate electorally, since the scope of economic policy change has been narrowed. ${ }^{4}$ Empirically, these studies have generally confirmed this negative relationship between globalization and electoral turnout and have thus provided evidence in favor of the argument that constraints on government action reduce turnout. Häusermann et al. (2018) take this perspective to the area of fiscal policy, and their results also suggest that constraints on government fiscal policy in the form of high government deficits and high government interest rates reduce turnout among citizens. ${ }^{5}$

However, until recently the literature on constraints on government action and turnout ignored the potential effect of fiscal rules on turnout, even though these rules specifically acts as formal constraints on government fiscal policy, through the existence of expenditure ceilings, rules for when public debt can be issued and numerical limits on government deficit and debt levels. Taking

\footnotetext{
${ }^{3}$ In the Riker and Ordeshook model this would represent a decrease in D.

${ }^{4}$ A similar arguments have been made about economic globalization causing a convergence of political parties' positions on economic issues (Steiner and Martin 2012; Ward et al. 2015).

${ }^{5}$ Contingent on citizens' level of education.
} 
the perspective from the government constraints literature, we should expect these rules to affect electoral turnout negatively in the countries they are enacted in.

A recent exception to the scholarly void regarding fiscal rules and turnout is a paper by HortalaVallve and Larcinese (2017) who develop a theoretical model which deals with a formal constraint on government fiscal policy choices. Here, the argument is that as a government faces more policy restrictions, especially within fiscal policy, voters will have less incentive to acquire political information. This will in turn lower turnout, especially among relatively poorer voters. ${ }^{6}$ Consequently, even fiscal policy constraints and rules specifically designed to increase the welfare of voters, including poorer voters, can increase turnout inequality and - under some circumstances lower redistribution and consequently negatively affect poorer voter's welfare through the turnout channel. $^{7}$ According to these arguments, we should expect fiscal rules not only to decrease aggregate turnout but also to increase turnout inequality. ${ }^{8}$ However, while building on a large theoretical and empirical literature within the turnout and redistribution research agenda (HortalaVallve and Larcinese 2017, 411-414), this paper is purely theoretical.

\footnotetext{
${ }^{6}$ In their model, policy restrictions do not always lead to a lower turnout among poorer voters (Hortala-Vallve and Larcinese 2017, 418). However, the model generally follows that logic that policy restrictions decrease the incentive to acquire political information which disproportionally decreases turnout among poorer voters, since they have less political information to begin with. This decreases their electoral turnout since some level of political information is a prerequisite for participating in elections (Hortala-Vallve and Larcinese 2017, 413-418).

7 Through the mechanisms of the well-known Meltzer and Richards (1981) model where the level of redistribution is determined by the relative income of the median voter, which is relatively lower and thus yield a higher level of redistribution if poorer voters actually turn out in elections. See also Larcinese (2007).

${ }^{8}$ Research also suggest that decreased overall turnout increases turnout inequality and vice versa (Bhatti et al. 2018).
} 
Thus, according to the theoretical and empirical literature on constraints on government action and turnout, fiscal rules should both decrease aggregate electoral turnout and increase turnout inequality. This article puts these arguments to empirical testing.

\section{Fiscal rules and aggregate turnout: Data and estimation}

To test the effect of fiscal rules on aggregate electoral turnout, I use a dataset of turnout in parliamentary elections in a wide variety of countries in the years 1985-2012. All countries - which regularly hold elections - hold parliamentary elections and most democratic legislative assemblies have substantial power over fiscal policy, ${ }^{9}$ and the enactment of the public budget is usually the prerogative of the legislature. Given that turnout determinants seem to differ between democracies and non-democracies (i Coma 2016), I restrict the study to democracies, which I define as countries having a score on the well-known polity 2 index above 5. I also look at the relation between fiscal rules and turnout among in a more restricted sample consisting of the more economically developed and political stable countries of the OECD, where government efficiency is greater and fiscal rules therefore should be expected to be more effective (Bergman and Hutchison 2015) and thus more likely to act as a de-facto constraint on government policy.

As the measure of electoral turnout I use turnout as percent of voting age population. This measure is a somewhat more uncertain measure of turnout than using turnout as percent of registered voters $^{10}$ but it has the advantage of taking into account the incentive to even register as a voter, which could also be affected by fiscal rules and other policy constraints. Using turnout as percent of

\footnotetext{
${ }^{9}$ Although this power might differ between countries (Wehner 2006).

${ }^{10}$ This is reflected by the fact that turnout in some cases exceed 100 percent in the data.
} 
registered voters yields largely similar results. ${ }^{11}$ Turnout data is from the International Institute for Democracy and Electoral Assistance's Voter Turnout Dataset (IDEA 2016).

The central independent variables are national fiscal rules. These rules thus excludes supranational fiscal rules such as those associated with currency unions such as the European Union's Economic and Monetary Union. The focus on national fiscal rules enables me to test the more pure effect of fiscal rules on electoral turnout, whereas potential effects of supranational fiscal rules might capture the turnout effects of closer political-economic integration rather than the effects of fiscal policy rules. National fiscal rules are measured by two types of variables for each type of fiscal rules as defined by the IMF (Schaechter et al. 2012, 7-9):

- Expenditure rule.

- Revenue rule.

- Deficit rule.

- Debt rule.

The main type of variable is a simple dummy which takes the value 1 if the country has a fiscal rule of the given type in place which has statutory or constitutional basis. These types of fiscal rules should at least officially be legally binding for fiscal policymakers and thus act as a formal constraint on national fiscal policy.

\footnotetext{
${ }^{11}$ Results are available upon request.
} 
The other type of fiscal rule variable is an index which measure the strength of each type of fiscal rule. A description of the construction of these indexes is found in the online appendix D. The data for fiscal rules is from the IMF's Fiscal Rules' Database (Bova et al. 2015).

As control variables, ${ }^{12}$ I include a number economic and political controls, which are generally viewed as influencing turnout level in the comparative turnout literature (Blais 2006). They include $\log$ of GDP per capita in constant dollars from the World Bank's Database to control for the economic development of the country, a dummy for whether the country has a proportional electoral system ${ }^{13}$ and a dummy for whether voting is compulsory, ${ }^{14}$ which have all been found to be positively associated with turnout. I also include the log of population from the World Bank's Database in order to control for changes in country population size, since turnout might be larger in smaller nations (Blais 2006, 117). Since the level of government debt might be endogenous to the enactment and strengthening of fiscal rules (Altunbas and Thornton 2017; Aaskoven 2018) and might also constrain government fiscal policy, ${ }^{15}$ general government gross debt as a percentage of GDP is also added as a control. Data from this variable is from the IMF's Economic Outlook database. Descriptive statistics can be found in the online appendix A.

\footnotetext{
${ }^{12}$ In appendix B, the aggregate turnout analysis is redone without the inclusion of these control variables. The results are mostly similar to the main estimations.

${ }^{13}$ From the World Bank's Database of Political Institutions (Beck et al. 2001).

${ }^{14}$ Data is from the Voter Turnout Dataset.

${ }^{15}$ See Häusermann et al.'s (2018) arguments.
} 
To estimate the effect of fiscal rules on turnout, I run a number of ordinary least squares models with country-fixed effects. Using country-fixed effects enables me to hold constant potential unobserved time-invariant factors which might confound both national fiscal rules as well as turnout level and general political culture. These include legal origin (Alt and Lassen 2006) and the historical nature of fiscal relations between the executive and legislative branch (Wehner 2006). ${ }^{16}$ By using country-fixed effects, I analyze changes in turnout within countries, since I analyze deviations from the country mean. Year-fixed effects are included in order to take a time trend into account which might correlate both with a development in electoral turnout and the tendency for more countries to adopt fiscal rules and strengthen their existing fiscal rules' frameworks (Schaechter et al. 2012, 10-12).

Using this estimation method, I am thus able compare turnout within a country in periods where the country had one or more fiscal rules in place to periods where the country did not have one or more fiscal rules in place. This approach resembles a difference-in-difference design and should identify the effect of fiscal rules on turnout assuming parallel trends (Angrist and Pischke 2009, 227-241). In order to address issues of autocorrelation, I cluster the standard errors at the country-level. The equation for the estimation can be seen below with countries index by $i$ and years by $t$.

$$
\text { Turnout }_{i t}=\beta_{1} \text { Fiscal rule }_{i t}++\beta_{2} X_{i t}+\gamma_{t}+\delta_{i}+\varepsilon_{i t}
$$

Where Turnout is turnout in country $i$ in an election at time $t$. Fiscal rule is either one of the dummies for a fiscal rule with statutory or constitutional basis or the index for the fiscal rule strength. $X$ is a vector of control, while $\gamma_{t}$ and $\delta_{i}$ is the year- and country-fixed effects respectively. $\varepsilon$ is the error term.

\footnotetext{
${ }^{16}$ A central justification for the use of unit-fixed effects models (Imai and Kim 2018).
} 


\section{Results: Aggregate turnout}

In table 1 , the results from the analysis of fiscal rules with statutory and/or constitutional basis on aggregate turnout are reported. Overall, the results do not support the argument that fiscal rules depress turnout as should be expected from the constraining argument. Only expenditure rule behaves as expected and seems to have a negative effect on turnout. An effect which is only statistically significant at the $\mathrm{p}<0.10$-level. However, its substantial size is non-trivial. The introduction of an expenditure rule with statutory and/or constitutional basis seem to lower turnout with about three percentage points on average. However, when running an F-test after the estimation in model five, we cannot reject the hypothesis that the effect of the expenditure rules dummy is equal to the other fiscal rules dummies. Government gross debt seems to have no statistically significant effect on turnout, although the coefficient is negative as expected.

Of the other cross-national determinants of turnout, which are included as controls, they either show no statistically significant effect on turnout, or for proportional electoral system the opposite than expected effect. However, the majority of these variable exhibit very little to no within-country variation in the analyzed time period, and changes to electoral system type and compulsory voting only occur in very few countries. ${ }^{17}$ When looking at democracies across time, there seems to be limited evidence in favor of the argument that fiscal rules, since they constrain government policy choices, depresses turnout. Only an expenditure rule seems to have a statistically significant negative effect on turnout. However, even there the effect is not strongly statistically significant and does not seem to be statistically different from the null effects of the other fiscal rules.

\footnotetext{
${ }^{17}$ For compulsory voting, only Italy changes from compulsory to non-compulsory voting over the analyzed period.
} 
Table 1: Fiscal rules dummies and turnout

\begin{tabular}{|c|c|c|c|c|c|}
\hline & (1) & $(2)$ & (3) & (4) & (5) \\
\hline Log of GDP per capita & $\begin{array}{l}-2.70 \\
(5.49)\end{array}$ & $\begin{array}{l}-2.57 \\
(5.47)\end{array}$ & $\begin{array}{c}-2.29 \\
(5.564)\end{array}$ & $\begin{array}{l}-2.38 \\
(5.50)\end{array}$ & $\begin{array}{l}-2.32 \\
(5.57)\end{array}$ \\
\hline Proportional electoral system & $\begin{array}{c}-6.87 \\
(4.06)^{*}\end{array}$ & $\begin{array}{c}-7.03 \\
(4.10)^{*}\end{array}$ & $\begin{array}{c}-6.93 \\
(4.07)^{*}\end{array}$ & $\begin{array}{l}-6.81 \\
(4.14)\end{array}$ & $\begin{array}{c}-6.90 \\
(4.08)^{*}\end{array}$ \\
\hline Compulsory voting & $\begin{array}{l}-1.67 \\
(3.54)\end{array}$ & $\begin{array}{l}-1.63 \\
(3.55)\end{array}$ & $\begin{array}{l}-1.73 \\
(3.60)\end{array}$ & $\begin{array}{l}-1.56 \\
(3.55)\end{array}$ & $\begin{array}{l}-1.86 \\
(3.61)\end{array}$ \\
\hline Log of population & $\begin{array}{l}-6.71 \\
(9.09)\end{array}$ & $\begin{array}{l}-6.62 \\
(9.05)\end{array}$ & $\begin{array}{l}-6.69 \\
(9.03)\end{array}$ & $\begin{array}{l}-6.75 \\
(9.03)\end{array}$ & $\begin{array}{l}-6.70 \\
(9.15)\end{array}$ \\
\hline General government gross debt & $\begin{array}{l}-0.03 \\
(0.02)\end{array}$ & $\begin{array}{l}-0.03 \\
(0.02)\end{array}$ & $\begin{array}{l}-0.03 \\
(0.02)\end{array}$ & $\begin{array}{l}-0.03 \\
(0.02)\end{array}$ & $\begin{array}{l}-0.03 \\
(0.02)\end{array}$ \\
\hline Expenditure rule & $\begin{array}{c}-2.90 \\
(1.56)^{*}\end{array}$ & - & - & - & $\begin{array}{c}-3.15 \\
(1.74)^{*}\end{array}$ \\
\hline Revenue rule & - & $\begin{array}{l}-2.49 \\
(4.04)\end{array}$ & - & - & $\begin{array}{l}-1.38 \\
(3.73)\end{array}$ \\
\hline Balanced budget rule & - & - & $\begin{array}{l}0.34 \\
(1.71)\end{array}$ & - & $\begin{array}{l}1.36 \\
(1.96)\end{array}$ \\
\hline Debt rule & - & - & - & $\begin{array}{l}-0.39 \\
(2.06)\end{array}$ & $\begin{array}{l}-0.83 \\
(2.66)\end{array}$ \\
\hline Country-fixed effects & Yes & Yes & Yes & Yes & Yes \\
\hline Year-fixed effects & Yes & Yes & Yes & Yes & Yes \\
\hline Number of countries & 103 & 103 & 103 & 103 & 103 \\
\hline Number of observations & 415 & 415 & 415 & 415 & 415 \\
\hline F-test p-value & - & - & - & - & 0.47 \\
\hline Within R-squared & 0.19 & 0.18 & 0.18 & 0.18 & 0.19 \\
\hline
\end{tabular}

The introduction of a fiscal rule, with the possible exception of an expenditure rule, does not seem to have an effect on electoral turnout. However, a concern might be that the introduction of some sort of national fiscal rule was preceded by a general trend towards higher or lower electoral turnout, which might influence the interpretation of the above results and invalidate the model as a difference-in-difference estimate. In figure 2, electoral turnout is therefore analyzed and plotted 
before and after the introduction of any fiscal rule with a statutory and/or constitutional basis. ${ }^{18}$ Looking at figure 2, there does not seem to be any statistically significant effect of the introduction of a fiscal rule. The results also suggest no systematic trend in electoral turnout before the introduction of a national fiscal rule with a statutory and/or constitutional basis.

Figure 2: Predicted turnout in the years before and after fiscal rule introduction

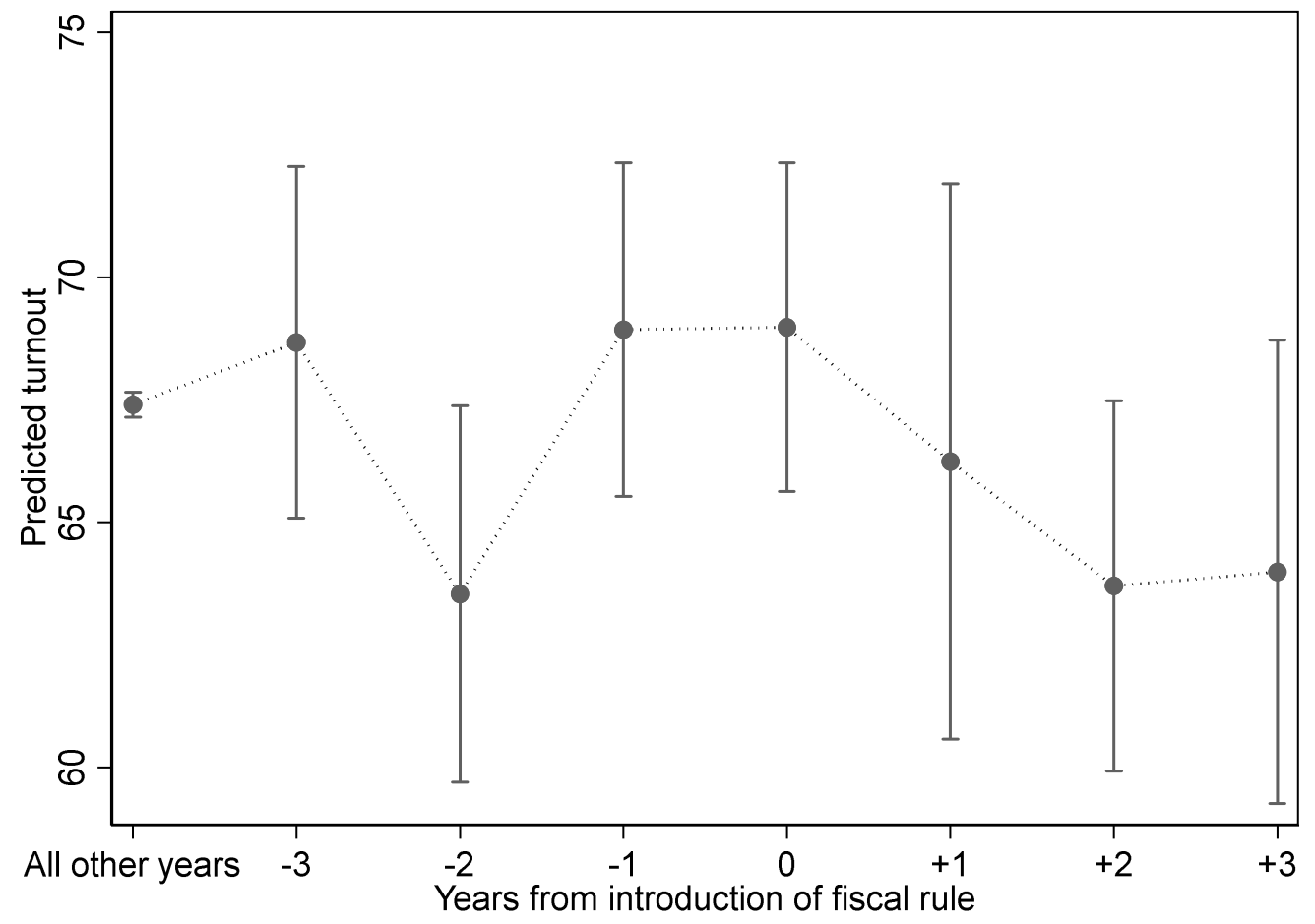

Note: Vertical lines show 90 pct. confidence intervals.

In a similar exercise in line with the difference-in-difference logic (Angrist and Pischke 2009, 237241), country-specific time trends are added to the estimations in table 1 . The results are largely similar to the results from table 1, only expenditure rule seems to have a statistically significant

\footnotetext{
${ }^{18}$ This figure is based on an estimation where the fiscal rules dummies are replaced with a number of dummies, which measure the time before and after the introduction of any national fiscal rule with either a statutory or constitutional basis. The table containing the results of this estimation can be found in appendix $C$.
} 
effect on turnout. However, this is no longer the case when the sample is restricted to OECD countries, where none of the fiscal rules dummies have any statistically significant impact on turnout once country-specific time trends are included. ${ }^{19}$

The results above are largely similar when the fiscal rules dummies are replaced with the indexes for fiscal rule strength. Only the strength of fiscal rules related to public expenditure seems to decrease average level of electoral turnout which provides substantial evidence against the argument that the constraint imposed by fiscal rules should decrease electoral turnout. These results are also robust to controlling for the influence of international organizations. These analyses can be found in appendix D.

In appendix E, the sample is restricted to the general political stable and affluent countries of the OECD and the estimation from table 1 and appendix D are rerun. While the results are largely similar to the results from the wider panel of democracies, the negative effect of expenditure rule existence and expenditure rule strength decreases substantially, and expenditure rule strength is no longer a statistically significant predictor of turnout rates. The results suggest either a substantial difference in the effect of expenditure rule on turnout levels between OECD countries and other electoral democracies, or more likely that the negative association between expenditure rule and turnout levels previously found might be statistical fluke rather than a true effect. Especially, since expenditure rules are much more common in OECD countries compared to other democratic

\footnotetext{
${ }^{19}$ Results are available upon request.
} 
countries. ${ }^{20}$ Furthermore, due to greater government efficiency in OECD countries, expenditure rules are probably more likely to be properly implemented and thus act as a de-facto constraint on government fiscal policy in OECD countries.

With the somewhat uncertain exception of expenditure rule, national fiscal rules do not seem to lower the aggregate level of electoral turnout in contrast to the argument that constraints on government action reduce turnout.

\section{Fiscal rules and inequality in turnout: Individual-level analysis}

The results from the previous section suggest that fiscal rules do not seem to have a particular robust effect on aggregate electoral turnout. However, since the analysis relies on aggregate turnout data, this approach to analyzing the relationship between fiscal rules and electoral turnout does not take into account potential heterogeneous effects of fiscal rules on different types of citizens' propensity to turn out in elections. In line with the logic of Hortala-Vallve and Larcinese's (2017) model, formal constraint on public policy - such as fiscal rules - might disproportionally decrease the incentive to turn out in elections among relatively poorer voters, while it might not decrease or even increase turnout propensity among more well-off voters. ${ }^{21}$ Taking this perspective, fiscal rules

\footnotetext{
${ }^{20}$ In 2014, about 7 percent of non-OECD democratic countries had an expenditure rules with a constitutional or statutory basis in place, whereas 26 percent of the OECD countries had such a rule in place.

${ }^{21}$ A contrarian argument is made by Häusermann et al. (2018) who argue that it is mainly well-educated citizens whose turnout propensity is affected by fiscal policy constraints. However, re-running the estimations in table 2 and interacting level of education, instead of relative income, with fiscal rules yields similar null results for these interactions. These results are available upon request.
} 
might not have an impact on overall turnout levels but might increase inequality in electoral turnout. $^{22}$ To address this issue, I turn to analyzing individual level data on voter turnout and relative income and its interaction with fiscal rules.

The data for this part of the analysis is the first 7 rounds of the European Social Survey (ESS), which consists of individual-level survey data for 32 European countries ${ }^{23}$ and has been collected every other year from 2002 to 2014 . To estimate the effect of fiscal rules on individuals' propensity to turn out in elections, I run a number of linear probability models, where the dependent variables is dummy which takes the value 1 if the respondent voted in the last national election. ${ }^{24} \mathrm{~A}$ linear probability model is used due to the difficulty of interpreting interaction terms in non-linear estimations (Ai and Norton 2003). However, the results are not substantially different when running the models with a logit estimator. ${ }^{25}$ As the independent variable, I use an interaction between the existence of the different type of fiscal rules in the country of the respondent and the respondent's

\footnotetext{
${ }^{22}$ However, aggregate turnout rate and turnout inequality appear to be highly correlated (Bhatti et al. 2018).

${ }^{23}$ These are Austria, Belgium, Croatia, Cyprus, the Czech Republic, Denmark, Estonia, Finland, France, Germany, Greece, Hungary, Iceland, Ireland, Israel, Italy, Lithuania, Luxembourg, the Netherlands, Norway, Poland, Portugal, Russia, Slovak Republic, Slovenia, Sweden, Spain, Switzerland, Turkey, Ukraine and the United Kingdom.

${ }^{24}$ The last national election year might not be identical to the current ESS survey year. Consequently, both the individual's income decile and the existence of national fiscal rules might, in some cases, have been different in the last election year. However, in most cases, both the income decile and the existence of national fiscal rules in the current year also reflect, at least partly, the situation in the last election year. Consequently, the interaction between these variables should produce, on average, the correct estimate, especially with the use of country-fixed effects.

${ }^{25}$ Results are available upon request.
} 
household's income decile, based on self-reporting in the ESS survey. ${ }^{26}$ If fiscal rules would increase the inequality in turnout between individuals from high income versus low income households, we should expect a positive and statistically significant effect of this interaction variable.

I also include a number of individual-level controls including marital status, whether the respondent is unemployed as well as the age and the square of age of the respondent. I also include the education level of the respondent. ${ }^{27}$ These types of predictors of individual-level turnout are some of the most commonly used in the literature (Smets and van Ham 2013, 348-350) and are also used in other studies, which relies on the ESS data to study turnout (Jensen and Jespersen 2017). The regression equation can be seen in equation 2, where each respondent is indexed by $r$, each round of the ESS survey by $e$ and each country by $i . Y$ is whether the respondent voted in the last national election, Fiscal rule is the existence of at fiscal rule with a statutory and/or constitutional basis in the relevant country at the time of the ESS round, and Income is the respondent's household's income decile. The constituting items of this interaction are also included in the estimation and are

\footnotetext{
${ }^{26}$ Since the ESS survey rounds in the years 2002, 2004 and 2006 recorded relative income on a 1-12 point scale, the household income scale is rescaled to run from 1 to 10 for these rounds.

${ }^{27}$ Education level is included as a dummy for each level of education based on the ISCED classification, which runs from no education to higher tertiary education.
} 
denoted by $C . X$ is a vector of controls, $\gamma_{e}$ is the ESS round-fixed effects, $\delta_{i}$ is the country-fixed effects, ${ }^{28}$ while $\varepsilon$ is the error term.

$$
\operatorname{Pr}\left[Y_{r e i}=1\right]=\beta_{1} \text { Fiscal rule }_{e i} X \text { Income }_{r e i}+\beta_{2} C_{r e i}+\beta_{3} X_{r e i}+\gamma_{e}+\delta_{i}+\varepsilon_{r e i}
$$

Since fiscal rules only exhibits variance at the country-level, standard errors are clustered by country.

The results for the linear probability models can be found in table 2 . Contrary to the expectation that fiscal rules increase turnout inequality, the interactions between the income decile variable and the different fiscal rules are all clearly statistically insignificant and some even have a negative sign. ${ }^{29}$ While relative income status does seem to be increase the propensity to have voted in the last election, in all estimations, this effect is not magnified by the existence of fiscal rules with statutory and/or constitutional bases. The results are similar if the dummies for the different fiscal rules are replaced with the fiscal rules indexes. These results can be found in appendix F. The results from the individual-level analysis thus suggest that national fiscal rules do not seem to increase inequality in turnout between high and low income individuals.

\footnotetext{
${ }^{28}$ Consequently, the fiscal rules dummies still capture within-country changes to fiscal rules. However, the interactions between fiscal rules and relative income levels are still not statistically significant if the country-fixed effects are removed from the estimation.

${ }^{29}$ As noted by Brambor et al. $(2006,74)$, a statistically insignificant interaction term might still hide a conditional statistically significant effect for some values on the mediating variable. However, plotting the interaction terms from table 2 still suggests no mediating effect of income on fiscal rules' effect on turnout. Results are available upon request.
} 
Table 2: Fiscal rules and inequality in turnout with ESS data

\begin{tabular}{|c|c|c|c|c|}
\hline & (1) & (2) & (3) & (4) \\
\hline Income decile & $\begin{array}{c}0.0101 \\
(0.0018)^{* * *}\end{array}$ & $\begin{array}{c}0.0096 \\
(0.0017)^{* * *}\end{array}$ & $\begin{array}{c}0.0090 \\
(0.0018)^{* * *}\end{array}$ & $\begin{array}{c}0.0097 \\
(0.0018)^{* * *}\end{array}$ \\
\hline Expenditure rule & $\begin{array}{c}0.0209 \\
(0.0162)\end{array}$ & - & - & - \\
\hline Expenditure rule $\mathrm{X}$ income decile & $\begin{array}{l}-0.0028 \\
(0.0027)\end{array}$ & - & - & - \\
\hline Revenue rule & - & $\begin{array}{l}-0.0307 \\
(0.0215)\end{array}$ & - & - \\
\hline Revenue rule $\mathrm{X}$ income decile & - & $\begin{array}{l}-0.0006 \\
(0.0033)\end{array}$ & - & - \\
\hline Balanced budget rule & - & - & $\begin{array}{l}-0.0059 \\
(0.0220)\end{array}$ & - \\
\hline Balanced budget rule $\mathrm{X}$ income decile & - & - & $\begin{array}{c}0.0019 \\
(0.0027)\end{array}$ & - \\
\hline Debt rule & - & - & - & $\begin{array}{c}-0.0293 \\
(0.0248)\end{array}$ \\
\hline Debt rule $X$ income decile & - & - & - & $\begin{array}{r}-0.0003 \\
(0.0039)\end{array}$ \\
\hline Married & $\begin{array}{c}0.0440 \\
(0.0059)^{* * *}\end{array}$ & $\begin{array}{c}0.0445 \\
(.0060)^{* * *}\end{array}$ & $\begin{array}{c}0.0440 \\
(0.0059)^{* * *}\end{array}$ & $\begin{array}{c}0.0440 \\
(0.0059)^{* * *}\end{array}$ \\
\hline Unemployed & $\begin{array}{c}-0.0572 \\
(0.0092)^{* * *}\end{array}$ & $\begin{array}{c}-0.0571 \\
(0.0092)^{* * *}\end{array}$ & $\begin{array}{c}-0.0571 \\
(0.0091)^{* * *}\end{array}$ & $\begin{array}{c}-0.0571 \\
(0.0092) * * *\end{array}$ \\
\hline Age & $\begin{array}{c}0.0274 \\
(0.0011)^{* * *}\end{array}$ & $\begin{array}{c}0.0274 \\
(0.0011)^{* * *}\end{array}$ & $\begin{array}{c}0.0274 \\
(0.0011)^{* * *}\end{array}$ & $\begin{array}{c}0.0274 \\
(0.0011)^{* * *}\end{array}$ \\
\hline Age squared & $\begin{array}{c}-0.0002 \\
(0.0000)^{* * *}\end{array}$ & $\begin{array}{c}-0.0002 \\
(0.0000)^{* * *}\end{array}$ & $\begin{array}{c}-0.0002 \\
(0.0000)^{* * *}\end{array}$ & $\begin{array}{c}-0.0002 \\
(0.0000) * * *\end{array}$ \\
\hline Education level dummies & Yes & Yes & Yes & Yes \\
\hline Country-fixed effects & Yes & Yes & Yes & Yes \\
\hline ESS round-fixed effects & Yes & Yes & Yes & Yes \\
\hline Number of observations & 240,600 & 240,600 & 240,600 & 240,600 \\
\hline R-squared & 0.1926 & 0.1926 & 0.1926 & 0.1926 \\
\hline
\end{tabular}

Note: Dependent variable is whether the respondent voted in the last national election. Country-clustered standard errors in parentheses.

$*: \mathrm{p}<0.10, * *: \mathrm{p}<0.05, * * *: \mathrm{p}<0.01$.

\section{Addressing causality: Difference-in-discontinuity evidence from Italian municipalities}

The results from the above analyses seem to suggest that the existence and strength of national fiscal rules have little to no robust effect on aggregate level turnout and do not seem to neither increase or decrease inequality in electoral turnout. However, while figure 2 suggest that the 
introduction of fiscal rules are not preceded by any noticeable trends in electoral turnout in the studied countries, issues of causal identification might still be raised. In order to address the causal identification of the null effect of fiscal rules on electoral turnout, I exploit a discontinuity among Italian municipalities previously used to study the pure fiscal policy effects of subnational fiscal rules (Grembi et al. 2016). This enables me not only but also to investigate the effect on fiscal rules on electoral turnout in an additional empirical setting but also, through the use of a populationbased regression-discontinuity design, to causally identify potential effects on turnout of being subject to a fiscal rule.

In 1999, Italian municipalities became subject to the so-called Domestic Stability Pact, which through the Italian annual budget law sought to restrain growth in the annual deficits of Italian municipalities. This deficit growth target was set to zero percent in in the years 1999, 2000, 2003 and 2004, 3 percent in 2001 and 2.5 percent in $2002 .{ }^{30}$ The sanction for non-compliance was severe cuts in central government transfers and reimbursements as well as a ban on municipal hiring, so this fiscal rules framework was both a substantial restraint on local fiscal policy and provided a large incentive to adhere by the rules locally. However, in 2001, the Italian central government relaxed these rules so that they did not cover municipalities below 5,000 inhabitants (Grembi et al. 2016, 6-7). In this way, this reform created a sharp discontinuity between municipalities subject to the fiscal rules and municipalities not subject to the fiscal rules, which makes this cut point ideal for identifying the causal effect of fiscal rules through a regression-discontinuity design including their potential effects on electoral turnout. If fiscal rules causally decrease electoral turnout, we should

\footnotetext{
${ }^{30}$ As noted by Grembi et al. $(2016,5-6)$ the rules were much more frequently changed after 2004 . So, like in their study, this study is restricted to the years 1999-2004.
} 
expect turnout in municipal elections to be higher in municipalities just below the 5,000 inhabitant threshold compared to municipalities just above the 5,000 inhabitant threshold.

However, since the 5,000 population threshold also increases the local mayor's wage, which previous research has found to substantially increase electoral turnout in Italian municipalities (De Benedetto and De Paola 2017), a simple regression discontinuity design is invalidated since the threshold policy treatment is confounded by this other policy change (Eggers et al. 2018). In order to address this issue, I follow the methodology of Grembi et al. (2016) and exploit that fact that the bump in the mayor's wage at 5,000 inhabitants was in place throughout the entire period while the exemption of the fiscal rules only happened from 2001 and onwards. As shown by Grembi et al. (2016, 8-12), adequately controlling for both the population threshold and the period where the fiscal rules were relaxed can causally identify the effects of relaxing the fiscal rules which can be denoted as a difference-in-discontinuity research design. The estimation itself is done by a local linear regression, where the effect of simultaneously being below the 5,000 threshold in the year 2001 and after is estimated for municipalities just below and just above the 5,000 inhabitant threshold. I follow Grembi et al. (2016) and estimate the bandwidth lengths using the updated software package by Calonico et al. $(2017)^{31}$ based on Calonico et al. (2014). I also report estimations from higher and lower bandwidths as a robustness check. The regression equation itself can be seen in equation 3 .

$$
\text { Turnout }_{i t}=\beta_{1} P R_{i} T_{i}+\beta_{2} P R_{i} T_{i} P I_{i t}+\beta_{3} T_{i} P I_{i t}+\beta_{4} P R_{i} P I_{i t}+\beta_{5} P R_{i}+\beta_{6} T_{t}+\beta_{7} P I_{i t}+\varepsilon_{i t}
$$

\footnotetext{
${ }^{31}$ Concretely, I use the rdrobust Stata command to estimate the 5,000 threshold effect for the observations before 2001 and the observations in 2001 and after. I then use the average of the bandwidths for these two estimations.
} 
The variable of interest to estimate the effect of relaxing fiscal rules on turnout is the $P R_{t} T_{i}$ interaction where $P R_{i}$ is a dummy for whether the municipality is below the 5,000 inhabitant threshold and $T_{i}$ is a dummy for the 2001 and after period. If being subject to fiscal rules would reduce electoral turnout, we should expect the coefficient for this interaction to be positive and statistically significant. $P I_{i t}$ is a variable measuring the distance to the 5,000 inhabitant threshold. The data for population size is from a version of the dataset used by Grembi et al. (2016) and is originally from the Italian Ministry of Interior, ${ }^{32}$ which is merged with municipal turnout data is from the Italian Home Office. ${ }^{33}$ The dataset only contains Italian municipalities with between 3,500 and 7,000 inhabitants and excludes municipalities in regions with special autonomy. ${ }^{34}$

The results for this difference-in-discontinuity design can be seen in table 3 . In column one, the estimation is done using a bandwidth length calculated using the Calonico et al. (2017) algorithm. If fiscal rules indeed decrease electoral turnout, we should expect the effect of the fiscal rules relaxation to be positive and statistically significant. However, contrary to this expectation, the beta coefficient in column one is strongly statistically insignificant. It stays insignificant with both decreasing and increasing the bandwidth lengths in columns two to four, and even in one instance becomes negative.

\footnotetext{
${ }^{32}$ Based on either the 1991 and 2001 Italian census (Grembi et al. 2016, 13).

${ }^{33}$ I am extremely grateful to Veronica Grembi for sharing the general municipal data and to Nicola Mastrorocco for providing the turnout data. Turnout data is not available for all municipalities in the Grembi et al. (2016) data.

${ }^{34}$ It also excludes a single municipality (Pantigliate) which had a recorded turnout level of over 100 percent in the 2004 election. Including this municipality does not change the results. These results can be found in appendix G.
} 
Table 3: Difference-in-discontinuity estimations

\begin{tabular}{lcccc}
\hline & $(1)$ & $(2)$ & $(3)$ & $(4)$ \\
\hline Effect of relaxing fiscal rules & 0.01 & -0.01 & 0.00 & 0.01 \\
& $(0.02)$ & $(0.03)$ & $(0.02)$ & $(0.02)$ \\
\hline Bandwidth & 564 & 400 & 800 & 1000 \\
Observations & 420 & 307 & 589 & 775 \\
\hline
\end{tabular}

Note: Dependent variable is turnout in municipal elections. Column one reports bandwidths based on the algorithm of

Calonico et al. (2017). Municipal-clustered standard errors in parentheses. *: p<0.10, **: p<0.05, ***: $\mathrm{p}<0.01$.

In figure 3, the difference-in-discontinuity result is shown visually following the methods of Grembi et al. (2016, 16-17). Here, the y-axis represents the within-municipality difference in turnout between the years where the fiscal rules were relaxed (in the year 2001 and beyond) and the years where these rules were in place for all municipalities (1999 and 2000) and the x-axis the distance to the 5,000 inhabitant threshold. Again, there is no evidence for a systematic increase in turnout below the 5,000 inhabitant threshold, where the fiscal rules were not in place after 2000 . These results suggest no effect of fiscal rules on electoral turnout in Italian municipalities. Even when the effects of fiscal rules are locally causally identified, fiscal rules do not seem to have any effect on electoral turnout. 
Figure 3: Difference-in-discontinuity estimate

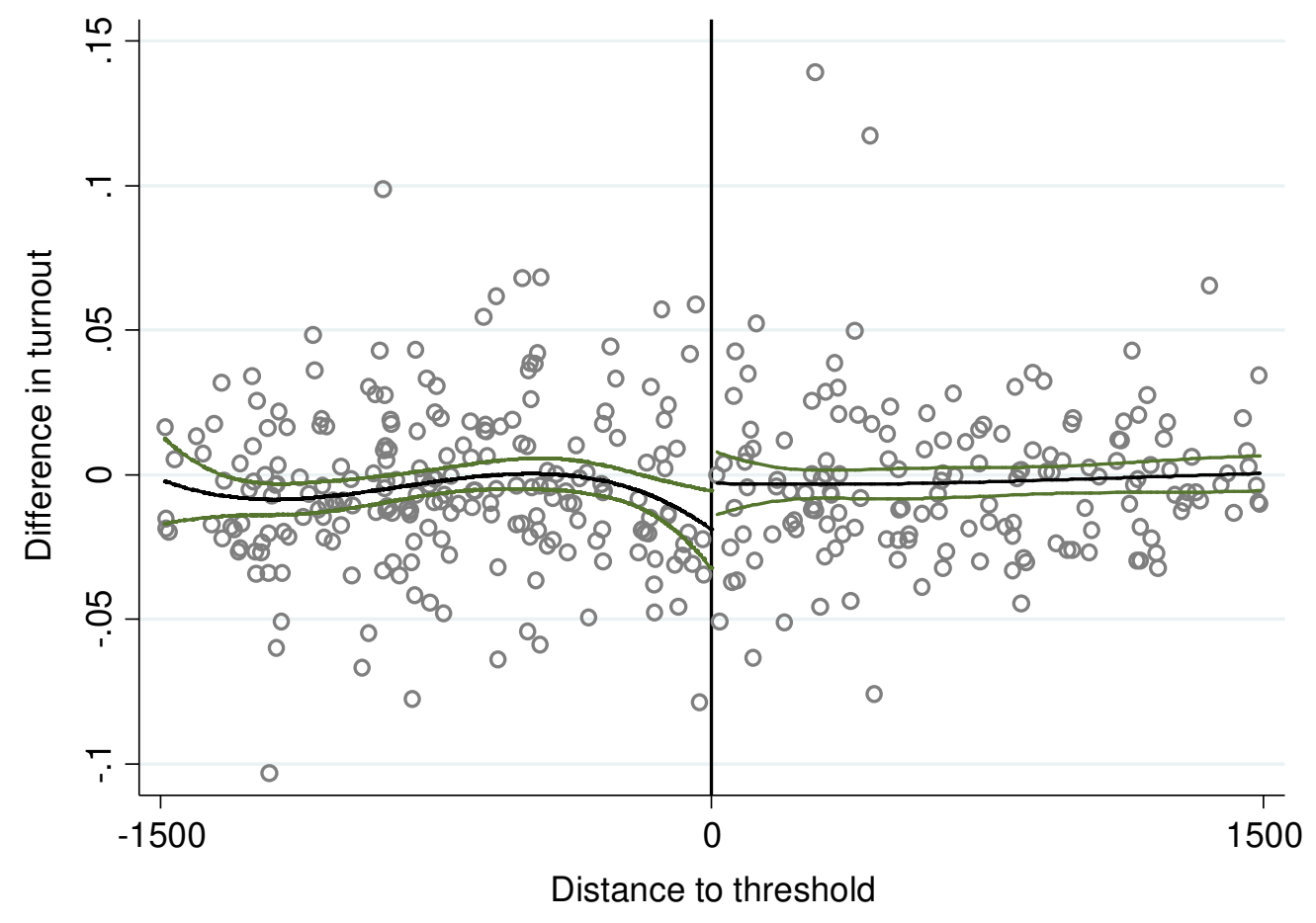

Note: The inner line represents a third-order polynomial fit. Outer lines represent 90 percent confidence intervals. 


\section{Discussion and conclusion}

A popular theoretical argument in the study of electoral turnout is that constraints on government action reduce electoral turnout. Within the area of government fiscal policy, fiscal rules, which are spreading fast among countries, could be an important constraint on government fiscal policy. This article has investigated empirically whether the enactment of fiscal rules and the stringency of the fiscal rules' framework matter for electoral turnout and turnout inequality in democracies. Contrary to recent theoretical arguments (Hortala-Vallve and Larcinese 2017), however, there seems to be little statistically robust evidence in favor of fiscal rules having a negative effect on within-country electoral turnout levels. Only the existence and strength of fiscal rules related to public expenditures has a statistically significant negative association with turnout. An effect which is not robust to restricting the panel sample to OECD countries where the effect of fiscal rules on turnout should be expected to be largest. An analysis of individual-level data from the European Social Survey also suggests that fiscal rules do not increase inequality in turnout propensity between individuals from low and high income households. Further evidence from a difference-in-discontinuity design using Italian municipal data suggest that these null findings are plausible causally identified. While fiscal rules might matter for government fiscal policy they do not seem to matter much for voters' willingness to participate electorally.

The question remains for why we observe these general non-findings? The obvious explanation is of course that fiscal rules might not really be a constraint on government fiscal policy, in which case it makes sense that they do not lower aggregate turnout levels or affect inequality in electoral turnout. It is still an on-going scholarly debate whether fiscal rules actually have a causal effect on fiscal policies (Heinemann et al. 2018). Another possibility is that even if fiscal rules really 
constrain fiscal policy, voters might not be aware of the existence and effectiveness of fiscal rules. A crucial assumption in the argument of Hortala-Vallve and Larcinese (2017) is that the voters actually know that public policy is constrained by a policy rule which might not be a realistic assumption. Another possibility is that voters might know both the existence and potential effects of fiscal rules but that they do not factor it in when making the decision to turn out to elections or not. Instead, non-instrumental drivers of turnout might be far more important than whether elected officials will be constrained in their fiscal policy choices. In this way, the article contributes to the classic and continuing discussion in political science about the contributions and limitations of instrumental and/rational choice models of the voting action (Aldrich 1993, Green and Shapiro 1994, 47-71; Enos and Fowler 2014).

However, even accepting that the eventual policy outcome of elections might matter for turnout, the results of this article suggest that perhaps not all formal and informal constraints on government action are created equal with regards to their effect on turnout. Many types of structural and institutional constraints on government policies might affect turnout negatively (Steiner and Martin 2012; Marshall and Fisher 2015; Steiner 2016; Häusermann et al. 2018) but the results of this article show that the story of increased government constraints as inevitably leading to lower citizen political engagement might be too simplistic. Future research should keep this in mind and perhaps also be more open to pursuing and publishing null results within this research agenda. As the results from Italian municipalities show, increased use of causal identification in this research area might be a fruitful way to pursue better effect estimates and to supplement previous country-level regression studies. 
The findings also speaks to discussions about inequality in voting and related distributive issues. In the wealthy OECD countries, where we should expect turnout inequality to be highest (Kasara and Suryanarayan 2015), the effects of fiscal rules on turnout were generally most statistically nonrobust. Furthermore, the results from the European Social Survey data also suggest that fiscal rules might not increase the effect of relative income status on the propensity to turn out in elections, at least in European countries. These results cast some doubt on whether fiscal rules really matters for not only total electoral turnout but also turnout inequality and subsequent the welfare of poorer voters. If fiscal rules do not matter for aggregate turnout or inequality in turnout, the results of this article speak to the wider scholarly and policy discussion about the distributional consequences of fiscal rules. At least the political participation channel suggested by Hortala-Vallve and Larcinese (2017) might not be the relevant channel for how fiscal rules affect redistribution and inequality.

The results of this article thus suggest that perhaps the issue of electoral and other types of political participation as well as the issue of inequality of political participation are lesser concerns in the discussion on the desirability of fiscal rules. The enactment and strengthening of national fiscal rules might indeed have distributional consequences, but the results of this article suggest that this might not happen through an electoral channel. In a time when fiscal rules are spreading fast among countries, policymakers and scholars should have these results in mind when discussing the pros and cons of fiscal rules. 


\section{References}

Ai, Chunrong, and Edward C. Norton. 2003. Interaction terms in logit and probit models.

Economics Letters 80 (1): 123-129.

Aldrich, John H.. 1993. Rational Choice and Turnout. American Journal of Political Science 37 (1), 246-278.

Alt, James E. and David Dreyer Lassen. 2006. Fiscal transparency, political parties, and debt in OECD countries. European Economic Review 50: 1403-1439.

Altunbas, Yener and John Thornton. 2017. Why Do Countries Adopt Fiscal Rules? The Manchester School 85 (1): 65-67.

Angrist, Joshua D., and Jörn-Steffen Pischke. 2009. Mostly Harmless Econometrics: An Empiricist's Companion. Princeton: Princeton University Press.

Beck, Thorsten, George Clarke, Alberto Groff, Philip Keefer, and Patrick Walsh. 2001. New tools in comparative political economy: The Database of Political Institutions. World Bank Economic Review 15 (1): 165-176.

De Benedetto, Marco Alberto, and Maria De Paola. 2017. Candidates' Education and Turnout: Evidence from Italian Municipal Elections. German Economic Review 18 (1): 22-50.

Bergman, U. Michael, and Michael Hutchison. 2015. Economic stabilization in the post-crisis world: Are fiscal rules the answer? Journal of International Money and Finance 52: 82-101.

Bhatti, Yosef, Jens Olav Dahlgaard, Jonas Hedegaard Hansen and Kasper Møller Hansen. 2018. Core and Peripheral Voters: Predictors of Turnout Across Three Types of Elections. Forthcoming Political Studies. 
Birch, Sarah. 2010. Perceptions of Electoral Fairness and Voter Turnout. Comparative Political Studies 43 (12): 1601-1622.

Blais, André. 2006. What Affects Voter Turnout? Annual Review of Political Science 9: 111-125.

Bova, Elva, Tidiane Kinda, Priscilla Muthoora, and Frederik Toscani. 2015. Fiscal Rules at a Glance. Washington D.C.: International Monetary Fund.

Brambor, Thomas, William Roberts Clark and Matt Golder. 2006. Understanding Interaction Models: Improving Empirical Analysis. Political Analysis 14 (1): 63-82.

Calonico, Sebastian, Matias D. Cattaneo, and Rocio Titiunik. 2014. Robust Non-parametric Confidence Intervals for Regression-Discontinuity Designs. Econometrica 82 (6): 2295-2336.

Calonico, Sebastian, Matias D Cattaneo, Max H. Farrell, and Rocio Titiunik. 2017. rdrobust: Software for Regression Discontinuity Designs. Stata Journal 17 (2): 372-404.

Chowhury, Anis, and Iyanatul Islam. 2012. Fiscal Rules - Help or hindrance? VOX, CEPR's Policy Portal, $4^{\text {th }}$ October 2012.

i Coma, Ferran Martinez. 2016. Turnout determinants in democracies and non-democracies. Electoral Studies 41: 50-59.

Cox, Gary W. 2015. Electoral Rules, Mobilization, and Turnout. Annual Review of Political Science 18: 49-68.

Downs, Anthony. 1957. An Economic Theory of Democracy. Boston: Addison-Wesley.

Eggers, Andrew C., Ronny Freier, Veronica Grembi and Tommaso Nannicini. 2018. Regression Discontinuity Designs Based on Population Thresholds: Pitfalls and Solutions. American Journal of Political Science 62 (1): 210-229. 
Enos, Ryan D. and Anthony Fowler. 2014. Pivotality and Turnout: Evidence from a Field Experiment in the Aftermath of a Tied Election. Political Science Research and Methods 2 (2): 309319.

Fernandez-Albertos, Jose. 2015.“The Politics of Central Bank Independence. Annual Review of Political Science 18: 217-237.

Franklin, Mark N. 2004. Voter Turnout and the Dynamics of Electoral Competition in Established Democracies Since 1945. New York: Cambridge University Press.

Gerber, Alan, Mitchell Hoffman, John Morgan, Collin Raymond. 2017. One in a Million: Field Experiments on Perceived Closeness of the Election and Voter Turnout. NBER Working Paper No. 23071.

Geys, Benny. 2006. 'Rational' Theories of Voter Turnout: A Review. Political Studies Review 4 (1): 16-35.

Green, Donald P., and Ian Shapiro. 1994. Pathologies of Rational Choice Theory. New Haven: Yale University Press.

Grembi, Veronica, Tommaso Nannicini, and Ugo Troiano. 2016. Do Fiscal Rules Matter? American Economic Journal: Applied Economics 8 (3): 1-30.

Heinemann, Friedrich, Marc-Daniel Moessinger, and Mustafa Yeter. 2018. Do Fiscal Rules Constrain Fiscal Policy? A Meta-Regression-Analysis. European Journal of Political Economy 51: 69-92. 
Hortala-Vallve, Rafael, and Valentino Larcinese. 2017. The Perverse Consequences of Policy Restrictions in the Presence of Asymmetric Information. Political Science Research and Methods 5 (3): $411-425$

Häusermann, Silja, Thomas Kurer, and Bruno Wüest. 2018. Participation in hard times: how constrained government depresses turnout among the highly educated. West European Politics 41 (2): $448-471$.

Imai, Kosuke and Song Kim. 2018. "When Should We Use Unit Fixed Effects Regression Models for Causal Inference with Longitudinal Data. Forthcoming American Journal of Political Science. International Institute for Democracy and Electoral Assistance (IDEA). 2016. Codebook for Voter Turnout data. Strömsborg: International IDEA.

Jensen, Carsten, and Bjarke Bøgeskov Jespersen. 2017. To have or not to have: Effects of economic inequality on turnout in European democracies. Electoral Studies 45: 24-28.

Kasara, Kimuli, and Pavithra Suryanarayan. 2015. When Do the Rich Vote Less Than the Poor and Why? Explaining Turnout Inequality across the World. American Journal of Political Science 59 (3); 613-627.

Larcinese, Valentino. 2007. Voting over Redistribution and the Size of the Welfare State: The Role of Turnout. Political Studies 55: 568-585

Lijphart, Arend. 1997. Unequal Participation: Democracy's Unresolved Dilemma. American Political Science Review 91 (1): 1-14 
Marshall, John, and Stephen D. Fisher. 2015 Compensation or Constraint? How Different

Dimensions of Economic Globalization Affect Government Spending and Electoral Turnout.

British Journal of Political Science 45 (2): 353-389.

Meltzer, Allan, and Scott Richards. 1981. A Rational Theory of the Size of Government. Journal of Political Economy 89 (5): 914-927.

Miles, Matthew R.. 2015. Turnout as Consent: How Fair Governance Encourages Voter Participation. Political Research Quarterly 68 (2): 363-376

Moskowitz, Daniel J. and Benjamin Schneer. 2018. Reevaluating Competition and Turnout in U.S. House Elections. Forthcoming Quarterly Journal of Political Science.

Riker, William H., and Peter C. Ordeshook 1968. A Theory of the Calculus of Voting. American Political Science Review 62 (1): 25-42.

Schaechter, Andrea, Tidiane Kinda, Nina Budina, and Anke Weber. 2012. Fiscal Rules in Response to the Crisis - Towards the "Next-Generation" Rules. A New Dataset. IMF Working Paper 12/187.

Smets, Kaat, and Carolien van Ham. 2013. The embarrassment of riches? A meta-analysis of individual-level research on voter turnout. Electoral Studies 32: 344-359

Steiner, Nils D. 2016. Economic globalisation, the perceived room to manoeuvre of national governments, and electoral participation: Evidence from the 2001 British General Election. Electoral Studies 41: 118-128

Steiner, Nils D., and Christian W. Martin. 2012. Economic Integration, Party Polarisation and Electoral Turnout. West European Politics 35 (2): 238-265.

Ward, Dalston, Jeong Hyun Kim, Matthew Graham, and Margit Tavits. 2015. How Economic Integration Affects Party Issue Emphases. Comparative Political Studies 48 (10): 1227-1259. 
Wehner, Joachim. 2006. Assessing the Power of the Purse: An Index of Legislative Budget Institutions. Political Studies 54 (4): 767-785.

Wolfinger, Raymond E., and Steven J. Rosenstone. 1980. Who Votes? New Haven: Yale University Press. 